\title{
Maciej Urbaniak
}

Uniwersytet Łódzki

e-mail: murb@uni.lodz.pl

\section{ODPOWIEDZIALNOŚĆ SPOLECZNA \\ JAKO KRYTERIUM OCENY WSTĘPNEJ \\ I OKRESOWEJ DOSTAWCÓW}

SOCIAL RESPONSIBILITY AS A CRITERION

FOR INITIAL AND PERIODIC ASSESSMENT

OF SUPPLIERS

DOI: $10.15611 /$ pn.2018.505.05

JEL Classification: M14, M21

Streszczenie: Celem artykułu jest przedstawienie koncepcji społecznej odpowiedzialności jako kryterium oceny wstępnej i okresowej dostawców. W ostatnim czasie można zauważyć, iż coraz więcej przedsiębiorstw (a zwłaszcza międzynarodowych koncernów), wdrażając swoje strategie oparte na idei zrównoważonego rozwoju, ocenia i kwalifikuje swoich dostawców, kierując się standardami etyki w prowadzeniu działalności gospodarczej. W artykule przeanalizowano wymagania stawiane przez koncerny międzynarodowe swoim dostawcom w zakresie wdrażania elementów koncepcji społecznej odpowiedzialności przedsiębiorstw. Podmioty gospodarcze będące nabywcami nie ograniczają się wyłącznie do stawiania rygorystycznych wymagań dostawcom. Wiele koncernów międzynarodowych oferuje swoim dostawcom specjalne programy wsparcia w zakresie wdrażania koncepcji społecznej odpowiedzialności.

Słowa kluczowe: ocena dostawców, społeczna odpowiedzialność przedsiębiorstw, zarządzanie łańcuchem dostaw.

Summary: The aim of the article is to present the concept of social responsibility as a criterion for initial and periodic supplier assessment. In the last period, one could notice that more and more companies (especially multinationals) implementing their strategies based on the idea of sustainable developmentevaluate and qualify their suppliers referring to ethical standards in the code of conduct. The article analyzes the requirements set by the multinationals to suppliers in the implementation of elements of the concept of corporate social responsibility. Enterprises which are buyers are not limited to putting stringent requirements on suppliers. Many multinationals offer their providers the special support programs for the implementation of the social responsibility concept.

Keywords: supplier assessment, corporate social responsibility, supply chain management. 


\section{Wstęp}

Analizując trendy światowe, można zaobserwować, iż coraz więcej koncernów międzynarodowych przy ocenie wstępnej i okresowej dostawców bierze pod uwagę kryterium odnoszące się do podejmowanych przez nich działań z zakresu społecznej odpowiedzialności przedsiębiorstw (Corporate Social Responsibility) [Kumara, Rahman 2015, s. 268-278]. Podmioty gospodarcze będące nabywcami swoje wymagania w stosunku do dostawców publikują często w specjalnych dokumentach w formie wytycznych (Supplier Corporate Social Responsibility Guidelines, np. Toyota, Mazda, Subaru, Renault-Nissan) czy kodeksów postępowania odnoszących się do tej koncepcji (Supplier Code of Conduct, np. ABB, Apple, Bayer BASF, Deutsche Post DHL, Microsoft, Nestlé, Siemens, Skanska).

Kodeksy postępowania odnoszące się do wdrażania zasad społecznej odpowiedzialności w formie kodeksów postępowania publikują także polskie koncerny, jak np. PKN Orlen, Polfarma, LW Bogdanka, PGE, PKP Energetyka.

Zarówno wytyczne, jak i kodeksy postępowania opierają się na zasadach Global Compact (odnoszących się do poszanowania praw człowieka, zapewnienia standardów pracy, ochrony środowiska oraz przeciwdziałania korupcji). Odnoszą się one także do innych międzynarodowych dokumentów, takich jak: Wytyczne Organizacji Współpracy Gospodarczej i Rozwoju dla Przedsiębiorstw Międzynarodowych (OECD Guidelines for Multinational Enterprises), standardy Międzynarodowej Organizacji Pracy (International Labour Standards - LO), wytyczne Międzynarodowej Organizacji Standaryzacyjnej (zawarte m.in. w normach ISO serii 9000 dotyczących zarządzania i zapewnienia jakości, ISO serii 14000 dotyczących zarządzania środowiskowego, ISO 19600 dotyczącej zarządzania systemem zgodności, ISO serii 22300 dotyczących zarządzania ciągłością działania i bezpieczeństwem społecznym, ISO 26000 dotyczącej społecznej odpowiedzialności, ISO serii 27000 dotyczących zarządzania bezpieczeństwem informacji, ISO serii 28000 dotyczących zarządzania bezpieczeństwem w łańcuchach dostaw, ISO serii 31000 dotyczących zarządzania ryzykiem, ISO 37500 dotyczącej zarządzania działalnością outsourcingową, ISO serii 50000 dotyczących zarządzania energią, ISO 55000 dotyczących zarządzania aktywami), wytyczne innych standardów zarządzania (Social Accountability 8000, publikowanych przez Social Accountability International, czy AccountAbility 1000, publikowanych przez Institute of Social and Ethical AccountAbility w zakresie CSR), wymagania standardów Occupational Health- and Safety Assessment Series 18000 w zakresie systemowego zarządzanie bezpieczeństwem i higieną pracy, a także wytyczne do opracowywania raportów z działań ukierunkowanych na wdrażanie koncepcji odpowiedzialności społecznej GRI (Global Reporting Initiative). 


\section{Założenia dotyczące metodyki wstępnej i okresowej oceny dostawców, uwzględniające kryteria odpowiedzialności spolecznej}

Koncerny międzynarodowe coraz częściej oprócz wymagań technicznych (zawartych w stosownych przepisach i specyfikacjach technicznych dotyczących wyrobów) przekazują także swoje specyficzne oczekiwania, jakie powinni spełniać oferenci, poprzez specjalnie publikowane wytyczne, przewodniki oraz kodeksy postępowania dla dostawców (uwzględniające również oczekiwania związane z wdrażaniem koncepcji społecznej odpowiedzialności) czy formularze ewaluacyjne (Self-Evaluation Questionnaires) służące do samooceny kontrahentów (w jakim stopniu są oni zdolni do spełnienia wymagań technicznych i organizacyjnych). Dostawcy zainteresowani współpracą z międzynarodowymi koncernami, wypełniając kwestionariusze samooceny, powinni przedstawić dowody świadczące o zrozumieniu i spełnieniu tych wymagań. Weryfikacja tych dowodów przeprowadzana jest poprzez audity, podczas których poddaje się ocenie:

- stopień spełnienia wymagań prawnych (w szczególności odnoszących się do bezpieczeństwa produktów i procesów oraz ochrony środowiska, a także bezpieczeństwa i warunków pracy);

- skuteczność wdrożenia systemów zarzadzania jakością, środowiskiem, bezpieczeństwem;

- nadzorowanie (planowanie, realizację i kontrolę) procesów operacyjnych (związanych z obsługą klienta, projektowaniem i rozwojem produktów, zakupami, produkcją, zabezpieczeniem i dostawą wyrobów do klientów);

- sposób i skuteczność przeprowadzania kontroli jakości surowców, materiałów, półproduktów i wyrobów gotowych;

- identyfikację i wizualizację wyrobów, procesów, infrastruktury;

- zapewnienie odpowiedniej dokumentacji (procedur/ instrukcji, zapisów) dla produktów i procesów;

- nadzorowanie zasobów (infrastruktury, technologii dla procesów, systemów informacyjnych, odpowiednich kwalifikacji, warunków pracy oraz świadomości zatrudnionych osób w odniesieniu do wymagań zawartych w kodeksach postępowania);

- zarządzanie aspektami środowiskowymi (ograniczanie zużycia surowców, energii, emisji gazów, odpadów);

- warunki bezpieczeństwa i higieny, a także warunki socjalne;

- gotowość i procedury reagowania na awarie i sytuacje losowe mogące zakłócić ciągłość realizacji procesów realizowanych w łańcuchach dostaw [Helin, Babri 2015, s. 41-53; Kumara i in. 2014, s. 268-278].

Podczas audytów bardzo często wykorzystuje się listy kontrolne z oceną punktową (checklist scoring) umożliwiające określenie zakresu i stopnia spełnienia wymagań przez potencjalnych dostawców [Ghadimi i in. 2017, s. 12-27]. 
Kolejnym etapem jest screening dostawcy $\mathrm{i}$ analiza zebranych danych $\mathrm{z}$ raportów samooceny (obejmującej stopień możliwości spełnienia oczekiwań klienta), spostrzeżeń zebranych podczas audytów w przedsiębiorstwie będącym źródłem zakupów czy wizyt referencyjnych (w siedzibach lub filiach klientów potencjalnych dostawców). Jakość techniczna produktów weryfikowana jest często poprzez zakup próbny lub zwrócenie się do dostawcy z prośbą o możliwość przetestowania produktu (próbnego użytkowania lub testów laboratoryjnych czy produkcyjnych).

Ze względu na perspektywę kształtowania długookresowych związków partnerskich pomiędzy podmiotami gospodarczymi przy ocenie wstępnej dostawców nie bez znaczenia jest także ich sytuacja prawno-finansowa (struktura prawna i udział właścicielski, posiadane tytuły prawne do dóbr materialnych i niematerialnych), wywiązywanie się ze zobowiązań (posiadane aktywa finansowe/ materialne/niematerialne, zadłużenie, poziom rentowności, płynność finansowa, udziały w innych przedsiębiorstwach, rodzaj i zakres posiadanych ubezpieczeń oraz gwarancji finansowych), które mogą decydować o stabilności oraz trwałości tych relacji w przyszłości. Wyżej wymienione kryteria nie są brane pod uwagę tylko przy wstępnej ocenie i kwalifikacji dostawców. Wiele międzynarodowych koncernów, zawierając umowy z dostawcami, zobowiązuje ich do podpisania także oświadczenia, obligującego ich do wprowadzania koncepcji społecznej odpowiedzialności poprzez stosowanie zasad zawartych w klauzulach tzw. praktyk biznesowych (Statement on Business Practices) oraz w klauzulach przestrzegania wymagań środowiskowych (Supplier Social \& Environmental Responsibility Agreement, np. HP) [www1]. Oświadczenia dotyczące praktyk biznesowych związane są między innymi z prowadzeniem działalności przy przestrzeganiu ściśle wszystkich obowiązujących przepisów prawnych i standardów etyki, niestosowaniem praktyk korupcyjnych, walką z próbami przekupstwa urzędników instytucji krajowych i zagranicznych, niedyskryminowaniem pracowników, ochroną międzynarodowych praw człowieka oraz odpowiedzialnością za środowisko.

Ocena okresowa dostawców uwzględniająca kryteria związane ze społeczną odpowiedzialnością najczęściej przeprowadzana jest przy użyciu formularzy samooceny. Służą one do oceny doskonalenia tychże działań przy zastosowaniu stosownych mierników, pozwalających zweryfikować stopień założonych celów w postaci osiągniętych wskaźników (aktualnych wyników). Przekazywane przez dostawców dane w postaci raportów (supplier sustainability report) są następnie weryfikowane poprzez audity drugiej strony (wykonywane przez auditorów i ekspertów przedsiębiorstwa będącego klientem) lub audity trzeciej strony (wykonywane przez auditorów i ekspertów jednostek niezależnych). Raporty te uwzględniają dane oparte na wskaźnikach ekonomicznych, środowiskowych i społecznych (zwracając szczególną uwagę na takie elementy, jak praktyki zatrudniania, respektowanie praw człowieka czy odpowiedzialność za produkt) [Gallego-Álvarez, Ortas 2017, s. 337-353; Sancha i in. 2016, s. 1934-1947].

Również wyniki audytów (zarówno drugiej, jak i trzeciej strony) dokumentowane są w stosownych raportach. W przypadku stwierdzenia w raportach niezgodności i/lub 
uwag dostawcy zobligowani są do wdrożenia stosownych (zapewniających skuteczność) działań korygujących i/lub zapobiegawczych (Corrective Actions/ Preventive Actions - CAPA).

Szczególną formą oceny stopnia wdrożenia koncepcji społecznej odpowiedzialności są audity certyfikacyjne. Niektóre międzynarodowe koncerny honorują w ramach oceny wstępnej i okresowej także wyniki audytów certyfikacyjnych zlecanych przez samych dostawców w celu potwierdzenia przez nich wymagań standardów międzynarodowych w zakresie CSR. Najbardziej rozpoznawalną certyfikacją jest ocena zgodności z wytycznymi opublikowanymi przez przez Social Accountability International. Jednakże zainteresowanie dostawców certyfikacją systemów zarządzania na zgodność Z wymaganiami standardu odpowiedzialności społecznej SA 8000 jest raczej umiarkowane. Do końca 2016 roku certyfikatem takim legitymowało się na świecie niecałe 4000 (3888) organizacji, głównie z Włoch (1081), Indii (953), Chin (654), Rumunii (112), Bułgarii (91), Wietnamu (91), Brazylii (68), Pakistanu (62). W większości były to małe i średnie podmioty (67,3\%, głównie z sektorów: tekstylnego (522), odzieżowego (380), budowlanego (244), usług sprzątających (178), spożywczego (146), skórzanego (101), metalowego (100), obuwniczego (98), chemicznego (91), elektronicznego (90), tworzyw sztucznych (84). Najczęściej certyfikację przeprowadzają renomowane jednostki certyfikujące, takie jak: Société Générale de Surveillance (668), Bureau Veritas Certification (665), Det Norske Veritas-Germanischer Lloyd (291), TÜV Rheinland (266), TÜV Nord (159), British Standard Institution (170), TÜV SÜD (119) [www2].

\section{Standaryzacja kryteriów oceny wstępnej i okresowej dostawców związanych ze społeczną odpowiedzialnością w wybranych sektorach}

Jedną z prób ujednolicenia kryteriów audytowania dostawców w zakresie kryteriów związanych ze społeczną odpowiedzialnością jest inicjatywa podjęta w 2011 roku przez sześć międzynarodowych koncernów z sektora chemicznego, takich jak: BASF, Bayer, Evonik Industries, Henkel, Lanxess i Solvay. Inicjatywa ta nosi nazwę Together for Sustainability - The Chemical Initiative for Sustainable Supply Chains. Została ona oparta na wytycznych United Nations Global Compact, the Responsible Care Initiative, promowanych przez International Council of Chemical Associations (ICCA). Jej celem jest wypracowanie wspólnych kryteriów audytowania i samooceny dostawców. Zamierzeniem jej członków jest, by przeprowadzanie auditu przez jednego z jej członków honorowane było przez pozostałych zgodnie z ideą: "An audit for one is an audit for all". Podobnie wynik samooceny dostawcy przeprowadzony przez jedną z zrzeszonych organizacji ma być honorowany przez pozostałe. Inicjatywa ma służyć dzieleniu się wynikami samooceny i auditów u dostawców, promowaniu doskonalenia ich działań w zakresie wdrażania koncepcji odpowiedzialności społecznej oraz wymianie dobrych praktyk w tym zakresie. Do inicjatywy tej przystąpiły także inne koncerny chemiczne, takie jak Akzo Nobel, Arkema, 
Brenntac, Clariant, Covestro, DSM, DuPont, Eastman, IFF, Merck, Sanofi, Syngenta oraz Wacker. Kryteria oceny podczas auditów oraz samooceny dostawców przyjęte przez Together for Sustainability zostały przedstawione w tabeli 1.

Tabela 1. Kryteria oceny podczas auditów oraz samooceny dostawców związane ze społeczną odpowiedzialnością przejęte w ramach inicjatywy Together for Sustainability

\begin{tabular}{|c|c|}
\hline Zarządzanie & $\begin{array}{l}\text { Ustanowione polityki i ciągłe doskonalenie } \\
\text { Odpowiedzialność za zarządzanie } \\
\text { Partnerzy } \\
\text { Szkolenia i kompetencje }\end{array}$ \\
\hline Środowisko & $\begin{array}{l}\text { Zgodność z wymaganiami prawnymi } \\
\text { dotyczącymi środowiska } \\
\text { Odpady } \\
\text { Emisje do powietrza i zmiany klimatu } \\
\text { Woda i ścieki } \\
\text { Zagospodarowanie i terenu i różnorodność biologiczna } \\
\text { Ziemia i wody gruntowe }\end{array}$ \\
\hline Zdrowie i bezpieczeństwo & $\begin{array}{l}\text { Bezpieczeństwo produktów } \\
\text { Bezpieczeństwo transport } \\
\text { Bezpieczeństwo produkcji i przechowywania } \\
\text { Gotowość na wypadek awarii } \\
\text { Pomoc medyczna } \\
\text { Nadzór nad bezpieczeństwem }\end{array}$ \\
\hline Praca i prawa człowieka & $\begin{array}{l}\text { Praca dzieci } \\
\text { Praca przymusowa } \\
\text { Godziny pracy } \\
\text { Minimalne wynagrodzenia } \\
\text { Wolność zrzeszania się } \\
\text { Dyskryminacja } \\
\text { Specjalne umowy o pracę } \\
\text { Infrastruktura i zakwaterowanie }\end{array}$ \\
\hline Kultura zarządzania & $\begin{array}{l}\text { Zobowiązania firmy } \\
\text { Poszanowanie prywatności i własności intelektualnej } \\
\text { Obszar ryzyka: Minerały konfliktowe } \\
\text { Obszar ryzyka: Ochrona zwierząt } \\
\text { Uczciwa konkurencja } \\
\text { Procedury dyscyplinarne i zażalenia }\end{array}$ \\
\hline
\end{tabular}

Źródło: [www3].

W ramach inicjatywy dostawcy poddawani są wstępnej oraz okresowej samoocenie, a następnie weryfikacji poprzez audit przez jednostki niezależne (takie jak SGS, Intertek, DQS i ERM). Samoocena i raportowanie jej wyników odbywa się z wykorzystaniem platformy administrowanej przez EcoVadis.

Kolejną próbą ujednolicenia kryteriów audytowania dostawców w zakresie kryteriów związanych ze społeczną odpowiedzialnością jest inicjatywa przedsiębiorstw 
zrzeszonych w Electronics Industry Citizen Coalition [Grimm i in. 2016, s. 19711984]. Organizację tę założono w 2004 roku w celu promowania wspólnego kodeksu postępowania w branży elektronicznej, informacyjnej oraz komunikacyjnej (Information and Communication Technologies - ICT). Obecnie zrzesza ona ponad 100 firm będących producentami gotowych produktów high-tech (takich jak Acer, Apple, Dell, Eastman Kodak, Flextronics, Hewlett-Packard, Hitachi, HTC, IBM, Konica Minolta, Lenovo, Lexmark, LG Electronics, Logitech, Medtronic, Microsoft, Motorola, Philips, Samsung, Sony, Texas Instruments, Toshiba, Xerox) oraz ich dostawców na całym świecie. Electronics Industry Citizen Coalition propaguje innowacyjne praktyki z zakresu działań związanych ze zrównoważonym rozwojem u dostawców. Działania te mają na celu m.in. pomoc dostawom w zakresie:

- wzrostu wydajności i efektywności procesów,

- poprawy warunków pracy i doskonalenia kwalifikacji personelu,

- ograniczania poziomu ryzyka zagrożeń w łańcuchu dostaw w celu zapewnienia ciągłości procesów realizowanych przez partnerów,

- poprawy oddziaływania na środowisko naturalne,

- promowania działań etycznych w relacjach z interesariuszami.

Przedsiębiorstwa zrzeszone w tej organizacji wspólnie wypracowują standardy w zakresie kwestionariuszy samooceny dostawców, kryteriów ich auditowania, czy wytyczne dla kodeksów postępowania etycznego (EICC Code of Conduct) [Liu i in. 2015, s. 2787-2803]. Aktualny protokół audytowy EICC, wersja 5.1, został ratyfikowany w 2016 roku. Kodeks postępowania EICC, stanowiący podstawę oceny dostawców w zakresie wdrażania koncepcji społecznej odpowiedzialności, składa się z 5 rozdziałów, obejmujących 43 kluczowe zasady:

Tabela 2. Kryteria oceny podczas auditów oraz samooceny dostawców przyjęte przez Electronics Industry Citizen Coalition

\begin{tabular}{|l|l|}
\hline \multirow{4}{*}{ Praca } & Swoboda wyboru zatrudnienia \\
\cline { 2 - 3 } & Młodzi pracownicy \\
\cline { 2 - 3 } & Godziny pracy \\
\cline { 2 - 3 } i higiena pracy & Wynagrodzenia i świadczenia \\
\cline { 2 - 3 } & Humanitarne traktowanie \\
\cline { 2 - 2 } & Brak dyskryminacji \\
\cline { 2 - 2 } & Swoboda zrzeszania się \\
\cline { 2 - 2 } & Przygotowanie na sytuacje awaryjne \\
\cline { 2 - 2 } & Urazy i choroby zawodowe \\
\cline { 2 - 3 } & Higiena przemysłowa \\
\cline { 2 - 2 } & Praca wymagająca sprawności fizycznej \\
\hline & Zabezpieczenie maszyn \\
\hline
\end{tabular}




\begin{tabular}{|c|c|}
\hline & Higiena, żywność i warunki mieszkaniowe \\
\hline & Komunikacja dotycząca zdrowia i bezpieczeństwa \\
\hline Środowisko & Zezwolenia i raportowanie środowiskowe \\
\hline & Zapobieganie zanieczyszczeniom i redukcja zasobów \\
\hline & Substancje niebezpieczne \\
\hline & Ścieki i odpady stałe \\
\hline & Emisje zanieczyszczeń do atmosfery \\
\hline & Ograniczenia materiałowe \\
\hline & \begin{tabular}{|l|} 
Zarządzanie wodą opadową \\
\end{tabular} \\
\hline & Zużycie energii i emisja gazów cieplarnianych \\
\hline Etyka & Rzetelność biznesowa \\
\hline & Unikanie niestosownych korzyści \\
\hline & Ujawnianie informacji \\
\hline & Własność intelektualna \\
\hline & Uczciwość biznesowa, reklama oraz konkurencja \\
\hline & Ochrona tożsamości i niedążenie do odwetu \\
\hline & Odpowiedzialne pozyskiwanie surowców mineralnych \\
\hline & Prywatność \\
\hline System & Zobowiązania firmy \\
\hline zarządzania & Odpowiedzialność kierownictwa \\
\hline & Wymaganie prawne oraz klientów \\
\hline & Ocena i zarządzanie ryzykiem \\
\hline & Cele doskonalenia \\
\hline & Szkolenia \\
\hline & Komunikacja \\
\hline & $\begin{array}{l}\text { Informacja zwrotna od pracowników i ich wkład } \\
\text { w działalność firmy }\end{array}$ \\
\hline & Audyty i oceny \\
\hline & Proces działań korygujących \\
\hline & Dokumentacja i zapisy \\
\hline & Odpowiedzialność dostawcy \\
\hline
\end{tabular}

Źródło: [www4].

Jednym z fundamentalnych złożeń EICC jest przeprowadzenie przez członków samooceny przy użyciu kwestionariusza (Self-Assessment Questionnaire-SAQ) oraz niezależnego procesu auditu walidacyjnego (Validated Audit Process -VAP), którego celem jest wykazanie stopnia zgodności z wymaganiami kodeksu. Przedsiębiorstwa, które poddadzą się audytowaniu i wykażą się najwyższym stopniem zgodności, mogą osiągnąć poziom platynowy (200 punktów), złoty (180 punktów) lub srebrny (160 
punktów). Audity prowadzą niezależne jednostki certyfikacyjne (takie jak British Standard Institution, Bureau Veritas Certification, Det Norske Veritas, Elevate, Intertek, Société Générale de Surveillance, TÜV Rheinland, Underwriters Laboratories, Verité), posiadające stosowną akredytację uprawniającą je do oceny zgodności z wytycznymi kodeksów postępowania określonymi przez EICC.

Innym przykładem opracowania wspólnych kryteriów kwalifikacji wstępnej i okresowej dostawców (w formie samooceny i audytów) jest Pharmaceutical Supply Chain Initiative (PSCI), która zrzesza 24 światowych producentów produktów farmaceutycznych (takich jak Astra Zeneca, Baxter, Bayer, Boehringer Ingelheim, GlaxoSmithKline, Johnson \& Johnson, Merck, Novartis, Novo Nordisk, Pfizer, Roche, Sanofi, Tekeda czy West). Pharmaceutical Supply Chain Initiative nie wypracowała jednolitego kodeksu postępowania dla dostawców. W ramach tej inicjatywy określono tylko jednolite kryteria oceny [www5]. Obejmują one 10 obszarów:

- systemy zarządzania,

- środowisko,

- emisje do powietrza,

- dostawy wody/wody opadowe/ścieki,

- zarząazzanie odpadami,

- nadzorowanie materiałów niebezpiecznych i raportowanie,

- azbest, polichlorowane bifenyle i substancje zubożające warstwę ozonową,

- dokumentacja dotyczącą bezpieczeństwa i higieny pracy,

- dokumentacja pracy,

- etyka.

W audytach dostawców realizowanych w ramach Pharmaceutical Supply Chain Initiative biorą udział także niezależne jednostki, takie jak British Standard Institution, Bureau Veritas, Société Générale de Surveillance czy TÜV Rheinland.

Na szczególną uwagę zasługują specyficzne wymagania przedsiębiorstw z sektora farmaceutycznego zawarte w opracowanych przez nich kodeksach postępowania dla dostawców. Wymagania te odnoszą się do przeprowadzania badań klinicznych z udziałem ludzi (które powinny być realizowane zgodnie z najwyższymi standardami medycznymi, naukowymi i etycznymi, a w szczególności z Deklaracją Helsińską) oraz do przeprowadzania badań z udziałem zwierząt (które powinny być realizowane w sposób humanitarny, maksymalnie zmniejszający ich stres, strach i ból). Badania z udziałem zwierząt mogą być wykonywane tylko wówczas, gdy nie istnieją naukowo uzasadnione i powszechnie akceptowane metody alternatywne.

Interesującą inicjatywą w sektorze producentów zabawek jest International Council of Toy Industries (ICTI), która powstała w 1975 roku jako zrzeszenie stowarzyszeń handlu zabawkami z całego świata. ICTI przyjęła kodeks postępowania już w 1995 roku w odpowiedzi na rosnące zapotrzebowanie na zgodne z przepisami, bezpieczne i zdrowe środowisko pracy dla osób zatrudnionych w fabrykach zabawek. Kodeks ten opiera się na pięciu filarach procesu monitorowania CARE (Care - troska, Awareness - świadomość, Responsible - odpowiedzialność, Ethical - etyka). Zrzeszeni 
w International Council of Toy Industries producenci zabawek oraz sieci handlowe kwalifikują swoich dostawców na podstawie wyników audytów przeprowadzonych przez jednostki niezależne (m.in. Bureau Veritas, Intertek, Société Générale de Surveillance) [www6]. Kryteriami oceny są wymagania zawarte w kodeksie postępowania, który obejmuje 13 kluczowych elementów:

- zgodność z przepisami prawa i prawa pracy,

- godziny pracy,

- wynagrodzenia,

- praca nieletnich,

- praca przymusowa,

- praca z ograniczeniem wolności,

- praktyki dyscyplinarne,

- dyskryminacja,

- reprezentacja pracownicza,

- obiekty,

- zapobieganie pożarom,

- zdrowie, bezpieczeństwo i środowisko (EHS)/ zdrowie i bezpieczeństwo / środowisko,

- pomieszczenia socjalne/stołówki/opieka medyczna.

Równie interesującą inicjatywę dotyczącą wspólnych kryteriów oceny dostawców w zakresie społecznej odpowiedzialności w sektorze jubilerskim podjęła Responsible Jewerly Council (RJC) [www7]. Kryteria oceny realizowanej podczas audytów wykonywanych w łańcuchu dostaw diamentów i złota zostały zawarte w 4 obszarach:

- etyka biznesu,

- prawa człowieka i wpływ na społeczeństwo,

- wpływ na środowisko,

- systemy zarządzania.

Audity w tym sektorze wykonywane są m.in. przez takie jednostki certyfikujące, jak: Bureau Veritas, Deloit, Intertek, ISOQAR, KPMG, Société Générale de Surveillance, Underwriters Laboratories.

Należy zwrócić uwagę, iż szczególnie istotnym kryterium oceny dostawców sektora wyrobów jubilerskich jest niewykorzystywanie przez dostawców minerałów pochodzących z obszarów ogarniętych konfliktami zbrojnymi (jak np. Demokratyczna Republika Konga, Rwanda, Uganda, Burundi, Sudan, Tanzania, Zambia, Angola, Republika Środkowej Afryki) [Partzsch, Vlaskamp 2016, s. 978-986].

\section{Programy rozwoju dostawców w zakresie odpowiedzialności społecznej}

Coraz częściej międzynarodowe koncerny starają się pomagać dostawcom w spełnieniu rygorystycznych wymagań, oferując im pomoc w postaci konsultacji i szkoleń w zakresie wdrażania koncepcji społecznej odpowiedzialności [Trapp, Sarkis 
2016, s. 2088-2100]. Dostawcy wspierani są poprzez dostarczanie specjalistycznej wiedzy w ramach szkoleń i specjalistycznego doradztwa. Przykładem tego typu programu jest ABB's Supplier Sustainability Development Program (SSDP), który szczególną uwagę poświęca dostawcom z Brazylii, Chin, Indii, Meksyku, Kolumbii, Peru, Turcji, Indonezji, Tajlandii, Wietnamu i RPA. Pomaga im spełnić wymagania zawarte w kodeksach postępowania, koncentrując się w szczególności na zapewnieniu godziwych warunków oraz bezpieczeństwie i higienie pracy, a także poprawie oddziaływania na środowisko [www8]. Pomoc dostawcom udzielana jest $w$ formie szkoleń oraz udziału ekspertów w prowadzeniu audytów wewnętrznych i wykorzystaniu list kontrolnych. Innym przykładem takich działań jest Volkswagen, który dostawcom w ramach programu Sustainability in the Supply Chain udziela wsparcia w formie materiałów szkoleniowych dostępnych na platformie VW B2B-Platform, które umożliwiają przeprowadzenie samooceny [www9]. Dostawcy, którzy nie są w stanie w wysokim stopniu spełnić tych wymagań, mogą uzyskać pomoc w formie bezpośredniego coachingu, który prowadzony jest przez zespół ekspertów (Ad-hoc-Expert-Team), składający się ze specjalistów zakresu ochrony środowiska, zasobów ludzkich, zarządzania bezpieczeństwem i higieną pracy, bezpieczeństwem zakupów, jak i zapewniania jakości produktów. Przy udziale ekspertów opracowują oni plany doskonalenia dostawców w zakresie wdrażania koncepcji CSR, które zakładają osiąganie celów w postaci docelowych wskaźników związanych z ochroną środowiska (takich jak ograniczanie zużycia substancji szkodliwych, emisji dwutlenku węgla), poprawą bezpieczeństwa produktów (zmniejszanie ilości wad produkcyjnych, zgłaszanych reklamacji przez klientów) i procesów (ograniczanie ryzyka wypadkowości czy sytuacji awaryjnych).

Należy zatem stwierdzić, iż wymagania stawiane dostawcom przez międzynarodowe koncerny, a także oferowane programy ich rozwoju przyczyniają się wyraźnie do ich trwałego, zrównoważonego rozwoju, koncentrując się na zagwarantowaniu bezpieczeństwa produktów i procesów w łańcuchach dostaw, niwelowaniu negatywnego wpływu na otoczenie, poprawie warunków pracy oraz promowaniu etycznego zachowania w relacjach gospodarczych [Wilhelm i in. 2016, s. 196-212; Winter, Lasch 2016, s. 175-190]. Wdrażanie tej koncepcji wpływa znacząco na ograniczanie ryzyka zagrożeń w łańcuchu dostaw i przyczynia się do zapewnienia ciągłości procesów realizowanych przez partnerów i poprawy ich wizerunku [Prasanna Venkatesan, Goh 2016, s. 124-142].

\section{Zakończenie}

Rekapitulując zaprezentowane $\mathrm{w}$ artykule rozważania, należy stwierdzić, iż przedstawione rozwiązania w zakresie standaryzacji kryteriów oceny wstępnej i okresowej dostawców, związanych ze społeczną odpowiedzialnością w wybranych sektorach, ściśle opierają się na najnowszych wytycznych międzynarodowych oraz na światowych standardach zarządzania publikowanych przez ISO. Porównując róż- 
nice pomiędzy sektorami w zakresie kryteriów oceny, można wyraźnie dostrzec, iż wynikają one z ich specyfiki (przetwarzanych surowców, materiałów oraz oferowanych wyrobów gotowych w łańcuchach dostaw). Istotnym atutem przedstawionych zestandaryzowanych kryteriów jest ich kompleksowość, systematyczność przeprowadzanych ocen i samoocen dostawców oraz zaangażowanie w procesy audytów doświadczonych, niezależnych jednostek weryfikujących.

\section{Literatura}

Gallego-Álvarez I., Ortas E., 2017, Corporate environmental sustainability reporting in the context of national cultures: A quantile regression approach, International Business Review, vol. 26, s. 337353.

Ghadimi P., Dargi A., Heavey C., 2017, Sustainable supplier performance scoring using audition check-list based fuzzy inference system: A case application in automotive spare part industry, Computers \& Industrial Engineering, vol. 105, s. 12-27.

Gray R., Owen D., Sopher M.J., 1998, Setting up a control system for your organization, Nonprofit World, vol. 16, no. 3, s. 65-76.

Grimm J.H., Hofstetter J.S., Sarkis J., 2016, Exploring sub-suppliers'compliance with corporate sustainability standards, Journal of Cleaner Production, vol. 112, s. 1971-1984.

Helin S., Babri M., 2015, Travelling with a code of ethics: a contextual study of a Swedish MNC auditing a Chinese supplier, Journal of Cleaner Production, vol. 107, s. 41-53.

Kumara D.T., Palaniappan M., Kannanc D., Shankar K.M., 2014, Analyzing the CSR issues behind the supplier selection process using ISM approach, Resources, Conservation and Recycling, vol. 92, s. 268-278.

Kumara D., Rahman Z., 2015, Sustainability adoption through buyer supplier relationship across supply chain: A literature review and conceptual framework, International Strategic Management Review, no. 3, s. 110-127.

Li W.-Y., Chow P.-S., Choi T.-M., Chan H.-L., 2016, Supplier integration, green sustainability programs, and financial performance of fashion enterprises under global financial crisis, Journal of Cleaner Production, vol. 135, s. 57-70.

Liu Ch.-Ch., Yu Ch.-Ch., Wernick I.K., Chang Ch.-Y., 2015, Using the Electronic Industry Code of Conduct to evaluate green supply chain management: An empirical study of Taiwan's Computer Industry, Sustainability, no. 7, s. 2787-2803.

Partzsch L., Vlaskamp M.C., 2016, Mandatory due diligence for 'conflict minerals' and illegally logged timber: Emergence and cascade of a new norm on foreign accountability, The Extractive Industries and Society, no. 3, s. 978-986.

Prasanna Venkatesan S., Goh M., 2016, Multi-objective supplier selection and order allocation under disruption risk, Transportation Research, vol. 95, s. 124-142.

Sancha C., Gimenez C., Sierra V., 2016, Achieving a socially responsible supply chain through assessment and collaboration, Journal of Cleaner Production, vol. 112, s. 1934-1947.

Trapp A.C., Sarkis J., 2016, Identifying Robust portfolios of suppliers: a sustainability selection and development perspective, Journal of Cleaner Production, vol. 112, s. 2088-2100.

Wilhelm M., Blome C., Wieck E., Xiao Ch.Y., 2016, Implementing sustainability in multi-tier supply chains: Strategies and contingencies in managing sub-suppliers, International Journal of Production Economics, vol. 182, s. 196-212.

Winter S., Lasch R., 2016, Environmental and social criteria in supplier evaluation - Lessons from the fashion and apparel industry, Journal of Cleaner Production, vol. 139, s. 175-190. 
www1, http://www8.hp.com/h20195/v2/getpdf.aspx/c04900239.pdf.

www2, http://www.saasaccreditation.org/certfacilitieslist.

www3, http://tfs-initiative.com/assessment-process/.

www4, http://www.sgs.pl/pl-PL/Sustainability/Social-Sustainability/Social-Responsibility-SR/EICC-

-Program.aspx.

www5, https://pscinitiative.org/home.

www6, http://www.toy-icti.org/.

www7, http://www.responsiblejewellery.com/.

www8, http://www.abb.com/cawp/seitp202/99c92840ff1f37aec1257cb40037ele6.aspx.

www9, https://www.volkswagenag.com/presence/nachhaltigkeit/documents/policy-intern/2014\%20

Sustainability\%20in\%20Supplier\%20Relations.pdf. 